Review

\title{
Therapeutic Strategies for the Treatment of Chronic Hyperuricemia: An Evidence-Based Update
}

\author{
Arrigo F. G. Cicero ${ }^{1,+}+$, Federica Fogacci ${ }^{1,+}\left(\mathbb{C}\right.$, Masanari Kuwabara ${ }^{2}\left(\mathbb{D}\right.$ and Claudio Borghi ${ }^{1, *}(\mathbb{C}$ \\ 1 Hypertension Research Unit, Department of Medical and Surgical Sciences, University of Bologna, \\ 40126 Bologna, Italy; arrigo.cicero@unibo.it (A.F.G.C.); federicafogacci@gmail.com (F.F.) \\ 2 Cardiology Department and Intensive Care Unit, Toranomon Hospital, Tokyo 40138, Japan; \\ kuwamasa728@gmail.com \\ * Correspondence: claudio.borghi@unibo.it; Tel.: +39-512142224 \\ + These authors contributed equally to this work.
}

Citation: Cicero, A.F.G.; Fogacci, F.; Kuwabara, M.; Borghi, C. Therapeutic Strategies for the Treatment of Chronic Hyperuricemia: An Evidence-Based Update. Medicina 2021, 57, 58. https://doi.org/ 10.3390/medicina57010058

Received: 15 November 2020 Accepted: 7 January 2021 Published: 10 January 2021

Publisher's Note: MDPI stays neutral with regard to jurisdictional clai$\mathrm{ms}$ in published maps and institutional affiliations.

Copyright: () 2021 by the authors. Licensee MDPI, Basel, Switzerland. This article is an open access article distributed under the terms and conditions of the Creative Commons Attribution (CC BY) license (https:// creativecommons.org/licenses/by/ $4.0 /)$.

\begin{abstract}
This article aims to critically review the evidence on the available therapeutic strategies for the treatment of hyperuricemia. For this reason, several papers were reviewed. Xanthine oxidase inhibitors are the safest and most effective uric acid lowering drugs for the management of chronic hyperuricemia, while the efficacy of uricosuric agents is strongly modulated by pharmacogenetics. Emergent drugs (lesinurad, peglotidase) were found to be more effective for the acute management of refractory hyperuricemia, but their use is supported by a relatively small number of clinical trials so that further well-designed clinical research is needed to deepen their efficacy and safety profile.
\end{abstract}

Keywords: hyperuricemia; uric acid; uric acid-lowering drugs; xanthine oxidase inhibitors; uricosurics

\section{Introduction}

Uric acid [UA] is mostly produced in the intestine and liver, as the final product of purine catabolism. This metabolic pathway has been highly conserved during the evolutionary process in most living species, with some exceptions such as Dalmatian dogs and some birds [1]. During normal homeostasis, serum levels of UA [SUA] are kept lower than $7 \mathrm{mg} / \mathrm{dL}$ in men and $6 \mathrm{mg} / \mathrm{dL}$ in women [2], mainly thanks to a complex regulation process involving the renal transport systems. However, chronic hyperuricemia might depend on the overproduction of UA and/or a reduced UA renal excretion [3], even though new pathogenic mechanisms also focus on ABCG2 expression in the intestine and the gut microbiota [4]. A number of factors are involved in determining SUA levels, including age (i.e., the prevalence of hyperuricemia increased from the age of 60 years, reaching a plateau after the age of 70 years), sex, cell renewal factor, renal function, and exogenous factors (i.e., dietetic factors, e.g., fructose, purine, and alcohol intake) [5].

Even though very high SUA is a well-known risk factor for gout, SUA levels at the upper limits of normal were shown to increase the chance of developing cardiovascular disease, type 2 diabetes, and chronic kidney disease [CKD] in the general population [6], and the risk of developing metabolic syndrome in elderly [7]. Recent evidence coming from the large epidemiological URRAH study shows that SUA is associated with a significantly increased risk of heart failure (hazard ratio, 1.65 [95\% confidence interval-CI, 1.28-2.11]), fatal heart failure (hazard ratio, 1.65 [95\% CI, 1.28-2.11]), total mortality (hazard ratio, 1.53 [95\% CI, 1.21-1.93]), and cardiovascular death (hazard ratio, 2.08 [95\% CI, 1.15-2.97]; $p<0.001$ ) [8,9]. The risk seems to increase with SUA levels lower than the ones associated with an increased risk of gout and even lower to the currently considered normal values [10].

Elevated serum UA levels has been associated with greater inflammatory status and greater risk of mortality also in patients with a history of cardiovascular disease and in particular after myocardial infarction [11,12]. 
Worldwide the percentage of adults with hyperuricemia has been increasing over the past decades and, lately, novel insights into the pathophysiology of this disorder has led to significant advancement in its management which uses traditional agents for mild-to-moderate disease and cutting-edge drugs for individuals with severe or refractory hyperuricemia [13]. Therefore, to recognize which patients mainly overproduce UA, which ones mainly under excrete it, and which ones suffer from both of these conditions is of fundamental importance in clinical practice. This initial differentiation could lead to a more appropriate use of the available UA lowering drugs based on their pharmacodynamics [14].

This review aimed to summarize the main clinical indications and the pharmacological profile of the most clinically tested UA lowering drugs.

\section{Drugs Reducing the Generation of Uric Acid: The Xanthine Oxidase Inhibitors}

Xanthine oxidase $[\mathrm{XO}$ ] is the form of enzyme xanthine dehydrogenase responsible for converting hypoxanthine to UA in the purine metabolism pathway. During this process, there is the production of reactive oxygen species [ROS] [15]. When produced in excess, ROS reduces the synthesis of nitric oxide and lead to endothelial dysfunction [15]. A meta-analysis pooling data from 81 randomized clinical trials (RCTs) (N. 10684 included patients) showed that the xanthine oxidase inhibitors [XOIs] decreases the risk of total and serious cardiovascular events [Odds Ratio-OR $=0.60, p=0.001$ and $\mathrm{OR}=0.64, p<0.01$ respectively] and onset/worsening hypertension $[\mathrm{OR}=0.54, p=0.002]$ in comparison with placebo. Moreover, a sub-analysis pooling data from 9 trials and 616 hyperuricemic subjects found that XOIs are more effective in secondary prevention, reducing the occurrence of major cardiovascular adverse events in those high-risk patients [Relative Risk-RR $=0.42$, $p<0.01$ ] [16]. Certainly, the potential benefits attributed to XOIs may rely on their antioxidant properties other than SUA reduction, by the inhibition of ROS production [17].

These agents are the first line in urate-lowering therapy for gout, being effective in most hyperuricemic patients with an acceptable tolerability profile [18].

\subsection{Allopurinol}

Allopurinol and its metabolite oxypurinol are respectively analogs of hypoxanthine and xanthine, and decrease UA formation by binding and inhibiting XO [19]. This drug can be administered orally or parenterally, to treat gout and prevent the recurrence of kidney stones.

Allopurinol treatment is the mainstay in the prophylaxis of hyperuricemia in patients receiving chemotherapy [20]. Moreover, it was associated with an improvement in flowmediated dilation [21] and a slowdown in CKD evolution [22,23]. An ongoing clinical trial (ClinicalTrial.gov ID: NCT03865407) will clarify the effect of allopurinol treatment on renal function in pediatric CKD patients with high UA levels and establish whether it alters renal injury biomarkers.

After oral administration, allopurinol is quickly absorbed in the upper gastrointestinal tract. The peak plasma concentration is reached in $~ 30$ min after ingestion, and the plasma half-life is $2-3 \mathrm{~h}$ [24].

The main active metabolite of allopurinol is oxypurinol, which is filtered and partially reabsorbed in the kidneys, having the same mechanism of action as allopurinol but a plasma half-life of the order of 14-30 $\mathrm{h}$ [24].

Allopurinol has a dose-dependent SUA-lowering effect and is usually administered at a daily dose of $100 \mathrm{mg}$ to $600 \mathrm{mg}$ /day for the treatment of chronic hyperuricemia [25]the maximum daily dose can however reach 800-900 mg/day, by country and productlabel [21]. Notwithstanding that a meta-analysis has lately showed that only lower doses of allopurinol ( $\leq 300 \mathrm{mg} /$ day) can reduce the risk of cardiovascular events $(p<0.001)$ [26].

In general, patients are recommended to start on a low dose of allopurinol and then gradually increase it. This expedient allows to contain the risk of hypersensitivity syndrome [AHS] and provides a chance to prevent acute gout attacks immediately after starting the 
treatment [17]. Moreover, the risk of acute attacks of gout can be further prevented by the co-administration of an anti-inflammatory drug or low-dose colchicine [27].

The most common reported side effects related to allopurinol use include gastrointestinal distress and skin rash ranging in severity. In addition to adverse skin reactions, treatment-emergent adverse events include AHS (which is rare but also potentially fatal), hepatitis, interstitial nephritis, and eosinophilia. CKD patients treated with thiazides have an increased risk for developing AHS so that patients with renal impairment are recommended to use lower allopurinol doses. Furthermore, pharmacogenomics plays a role in the safety of allopurinol use and the risk of serious adverse events augments in patients with the HLA-B*5801 haplotype, highly prevalent in Thai and Han Chinese ethnicities with at least stage 3 CKD [28].

Finally, allopurinol is contraindicated in patients on didanosine [29], while the concomitant administration of 300-600 mg/day allopurinol and azathioprine or mercaptopurine requires a reduction in dosage of the immunosuppressants to approximately one-third or one-fourth of the usual dose. In these cases, the therapeutic response and toxicity need to be monitored [30].

However, it must be acknowledged that these concerns can lead to allopurinol underdosing, and determining inadequate management of hyperuricemia of consequence [31].

\subsection{Febuxostat}

Febuxostat is an oral non-purine selective $\mathrm{XO}$ inhibitor able to blind and inhibit both the reduced and the oxidized form of $X O$. Febuxostat prevents enzyme turnover and blocks the active pterin-containing molybdenum center in enzyme-substrate complex, reducing the consequent ROS production [32]. Following oral administration, it is absorbed in the upper gastrointestinal tract and reaches the peak plasma concentration within $1 \mathrm{~h}$. Its plasma half-life is of the order of 5-8 h.

Febuxostat is metabolized and excreted mainly through hepatic conjugation. It is more effective than allopurinol in reducing SUA concentrations and exerts also anti-inflammatory properties on the endothelium $[33,34]$.

Febuxostat efficacy has been partly related to the inhibition of glycosaminoglycanbound and endothelial XO cell-bound [35]. By comparing the effect of febuxostat and allopurinol in gouty patients, febuxostat is more effective in preventing arterial stiffening over 1 year [36]. Contrarily, a recent phase 4 randomized, double-blind, crossover designed, a placebo-controlled clinical trial showed that febuxostat does not significantly improve coronary endothelial dysfunction in patients with known stable cardiovascular artery disease, even though it lowers SUA [37].

The recommended daily dosage of febuxostat is $80-120 \mathrm{mg} /$ day, even if remarkable reductions in SUA levels can be achieved also with lower dosages (i.e., $40 \mathrm{mg} /$ day). In particular, treatment with $40 \mathrm{mg} /$ day febuxostat seems to be able to reach the target value of SUA $(<6 \mathrm{mg} / \mathrm{dL})$ more easily than allopurinol $300 \mathrm{mg}$.

Febuxostat is indicated in hyperuricemic patients with gout, being a valid alternative treatment for individuals who experienced an allergic reaction with allopurinol [38]. No dosage adjustments are needed in patients with mild-to-moderate or severe hepatic impairment, though the American College of Rheumatology (ACR) recommends using low dose febuxostat $\left(40 \mathrm{mg} /\right.$ die) in patients with severe renal impairment (eGFR $<30 \mathrm{~mL} / \mathrm{min} / \mathrm{m}^{2}$ ) [39]. The ongoing LUMINA trial (ClinicalTrial.gov ID: NCT03200210) is investigating the longterm effect of the drug on cardiovascular outcomes in continuous ambulatory peritoneal dialysis patients with hyperuricemia.

Treatment-emergent adverse events associated with febuxostat include stomach pain, diarrhea, muscle pain, and slight elevations in transaminases [40]. These observations have been corroborated by a recent meta-analysis that, pooling data from 13 RCTs $(13,539$ patients overall), concluded that febuxostat has a similar cardiovascular safety when compared with allopurinol (side effects $\mathrm{OR}=0.72, p=0.55)$ and a halved risk of skin reactions $(\mathrm{OR}=0.50$, $p=0.01)$ [41]. 
Recently febuxostat has been shown to be better tolerated than allopurinol in hyperuricemic and gouty patients, especially when renal failure was present [adverse events $\mathrm{OR}=0.85$ [ [42]. Febuxostat has also been investigated for its nephroprotective activity in comparison with allopurinol and has recently been shown to safely reduce SUA in patients after kidney transplantation [43,44].

For these reasons, even if the 2016 guidelines of the European League Against Rheumatism [EULAR] suggest the use of febuxostat as an alternative SUA lowering agent [45], the latest American College of Physicians' guidelines (ACP 2017) suggest febuxostat as a first-line agent for the management of hyperuricemia [46]. The latest recommendation differs from the most recent one of the ACR placing allopurinol as the preferred first-line urate-lowering therapy, following the potential cardiovascular safety concerns attributed to febuxostat [39].

The Cardiovascular Safety of Febuxostat and Allopurinol in Patients with Gout and Cardiovascular Morbidities (CARES) trial reported a higher risk of cardiovascular mortality with the use of febuxostat versus control [47]. Following these results, the Food and Drug Administration (FDA) added a new boxed warning indicating that there is an increased risk of heart-related death and death from all causes with febuxostat. However, the available evidence regarding the effects of febuxostat on mortality and major cardiovascular adverse events in patients with gout is controversial. Most recently the Febuxostat versus Allopurinol Streamlined Trial (FAST) has yielded findings coming out in the opposite direction of CARES [48].

\subsection{Topiroxostat}

Topiroxostat is a selective XOI that has good oral bioavailability. Its pharmacologically active metabolite — namely the N-glucuronide topiroxostat (F11741) —is produced by the liver [49].

In vivo, topiroxostat causes a dose-dependent decrease in the excretion of urinary albumin [UAE] and the plasma activity of $X O$ [50]. Then, similar findings were safely confirmed in hyperuricemic patients with stage III CKD, where $160 \mathrm{mg}$ /day topiroxostat has been reported to decrease SUA levels and UAE [51].

Topiroxostat treatment was also shown to safely reach a significant decrease in SUA in hyperuricemic patients undergoing hemodialysis, at a lower dose rather than allopurinol [52]. Recently, the ETUDE trial has confirmed the positive impact of topiroxostat on renal function in patients with overt diabetic nephropathy [53]. However, clinical evidence on topiroxostat is yet limited.

\section{Drugs That Inhibit the Reabsorption of Uric Acid: The Uricosurics}

The uricosuric drugs increase the renal clearance of UA typically by inhibiting UA reabsorption in the renal proximal tubule.

To date, a putative role in UA secretion and reabsorption across the apical and the basolateral membrane of the proximal tubule has been assigned to several transporters [54] and genetic analyses such as genome-wide association studies [GWAS] have recently identified novel gene variants potentially associated with SUA levels and gout in humans [55]. The currently considered model involves a complex of proteins that serve the function of moving also other compounds across the proximal tubule's epithelial cells, and that joining together form the "urate (or UA) transportasome"' [56]. Among these transporter proteins, URAT1 (SLC22A12) plays a major role in the uptake of UA from the lumen [57]. Other transporters that are expressed in the apical membrane of kidney proximal tubule cells and with a role in the UA renal filtration are encoded by SLC17A1 (NPT1), SLC17A3 (NPT4), and ABCG2 (BCRP) [58].

GLUT9 (SLC2A9), located in the basolateral membrane, has a chief role in the transport of UA into the interstitium and blood [59]. A GWAS meta-analysis carried out on a sample of more than 28,000 individuals of European descent/White ethnicity has found SNPs associated with SUA levels in loci containing the SLC2A9, SLC17A1, SLC17A3, SLC22A12, 
and ABCG2 genes, among other novel loci [60]. A further GWAS meta-analysis has examined four phenotypes related to kidney function verifying that SLC2A9, SLC22A12, and ABCG2 loci are associated with UA concentration in 33,074 East Asian individuals [61]. A further GWAS meta-analysis including more than 140,000 European descents from the Global Urate Genetics Consortium [GUGC] has identified 16 novel and 10 previously known loci associated with SUA concentrations at genome-wide significance. These loci together explain up to 7\% of the variance in SUA, with ABCG2 and SLC2A9 loci contributing to $3.4 \%$ of the total amount. 17 of the loci associated with urate concentrations were also associated with gout [62]. Many of the SNPs associated with SUA concentrations in the European analysis have also been associated in cohorts of Japanese $(n=15,286)$, African-Americans $(n=5820)$, and individuals of Indian ancestry $(n=8340)$, though there are some differences which may be correlated to the change in allele frequencies between the four different populations considered. Several other genes have a potential role in UA transport in the renal proximal tubule in humans. These all have in vitro evidence, and only in part have been reported in GWAS as associated with SUA concentrations and/or gout $[63,64]$.

Uricosuric drugs can be safely administered in association with XOIs, offering promising perspectives for the treatment of refractory hyperuricemia [65]. Moreover, according to the EULAR [44] and ACR [45] recommendations for treating hyperuricemia, uricosurics are recommended as alternative first-line therapy for patients with failure to respond to XOIs or for those whose XOIs are contraindicated.

The main pharmacological characteristics of these drugs are resumed in Table 1.

\subsection{Probenecid}

Probenecid prevents the reabsorption of organic anions from the renal proximal tubule mainly by the inhibition of URAT1 (SLC22A12) transporter protein activity, as far as it is not excluded that it may also exert an effect upon OAT1 (SLC22A6), OAT4 (SLC22A11) and OAT10. Moreover, probenecid is a competitive inhibitor of the ATP release channel pannexin 1, being involved in the activation of the inflammasome, which releases IL-1ß that plays a pivotal role in the pathogenesis of atherosclerosis [66]. Contrarily, probenecid in vitro does not seem to affect GLUT9 (SLC2A9) at an effective pharmacological concentration of $1 \mathrm{mM}$ [67].

Probenecid absorption is essentially complete following oral administration and its half-life in plasma ranged from 4 to $12 \mathrm{~h}$, being dose-dependent. Its metabolism involves conjugation with glucuronic acid and oxidation of the alkyl side chains. Then, probenecid and its oxidized metabolites are largely bound to plasma proteins, especially to albumin [68]. Renal excretion is the major elimination pathway for the metabolites, while excretion of the parent drug is minimal and depends on urinary $\mathrm{pH}$.

Probenecid can improve the allopurinol SUA-lowering effect, but this favorable interaction is reported to be significant only in patients with eGFR $>50 \mathrm{~mL} / \mathrm{min}$ [27]. Contrarily, it should be used cautiously in subjects with $\mathrm{CrCl}<50 \mathrm{~mL} / \mathrm{min}$, due to the lack of longterm safety and efficacy data. Likewise, the same caution should be used also in the treatment of the eldest patients [69]. However, a large observational study of 38,888 elderly gouty patients has recently associated probenecid treatment with a modesty decreased risk of cardiovascular events compared to allopurinol, including myocardial infarction, stroke, and heart failure exacerbation [70]. Anyway, probenecid treatment has not been demonstrated to affect endothelial function in middle-aged non-hypertensive, overweight individuals [71].

Finally, probenecid decreases renal elimination and, of consequence, augments the plasma concentration of some organic acids, such as antibiotics and NSAID indomethacin when used concomitantly [72]. 
In the United States, probenecid and colchicine are available in combination. This association may be suggested in patients who need SUA-lowering therapy having recurrent acute gout attacks [73].

\subsection{Benzbromarone}

Benzbromarone is a uricosuric drug that is considered more effective than probenecid. It inhibits UA transport by URAT1 (SLC22A12) and GLUT-9 (SLC2A9) in vitro, though its action upon GLUT-9 may be minimal at therapeutic doses [74]. In vitro, it also acts against UA uptake by OAT1 (SLC22A6) [75].

After oral administration, benzbromarone is quick but poorly absorbed in the upper digestive tract and reaches its peak plasma concentrations in around 2-4 h. Its plasma

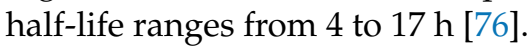

Its liver metabolism allows benzbromarone administration in patients with mild to moderate CKD, where it seems to significantly delay the long-term development of endstage renal disease most effectively than allopurinol [77], even if it should be avoided in patients with eGFR $<30 \mathrm{~mL} / \mathrm{min}$ for the risk of hepatotoxicity [78]. Moreover, it is not indicated in patients with UA kidney stones or blood dyscrasias [75].

Because of its potential hepatotoxicity, benzbromarone has been withdrawn from the USA and some European markets. However, despite this concern, it is still commonly prescribed in several countries of South America and Asia [79].

\subsection{Lesinurad}

Lesinurad was conditionally approved in the United States at the end of 2015 and in the European Union in 2016. It is a selective UA reabsorption inhibitor targeting the URAT1 transporter [78]. In addition to URAT1, lesinurad also inhibits the OAT4 transporter, being involved in diuretic-induced hyperuricemia. However, unlikely probenecid, lesinurad does not inhibit OAT1 or OAT3: this may hypothetically result in fewer drug-drug interactions (e.g., with methotrexate and several antibiotics, antivirals, and antiretrovirals which interact with human OAT1-3 and whose concentrations can be increased by combining with probenecid) [80].

Lesinurad is a moderate inducer of the CYP3A cytochrome so that it may lead to reduced exposure of drugs metabolizes by this cytochrome, such as statins, sildenafil, amlodipine, indomethacine, and colchicines [81,82]. Furthermore, it might reduce the effectiveness of the hormonal contraceptives, so that additional contraception methods are strongly recommended in patients in treatment with lesinurad. Then, the lesinurad use is not recommended in patients just in treatment with inhibitors of epoxide hydrolase, such as the valproic acid.

A phase 3 clinical trial pooling data from gouty patients with a story of intolerance or contraindication to treatment with XOIs, found a high incidence of serum creatinine elevations and renal-related adverse events with lesinurad $400 \mathrm{mg}$ monotherapy versus placebo [83]. For this reason, lesinurad should not be used as monotherapy. However, in combination with an XOI, lesinurad provides a dual mechanism to lower SUA by increasing renal UA excretion and reducing urate production. The CLEAR and the CRISTAL phase 3 trials respectively evaluated the effect of the addiction of lesinurad 200 or $400 \mathrm{mg}$ or placebo to allopurinol $\geq 300 \mathrm{mg}$ versus febuxostat $80 \mathrm{mg}$ in monotherapy and combined with lesinurad 200 or $400 \mathrm{mg}$ [84-86]. Safety data pooled from these phase 3 trials-overall including 1500 gouty patients-found a similar incidence of treatment-emergent adverse events across all the intervention groups.

A meta-analysis pooling data from 5 RCTs confirmed that lesinurad has an acceptable safety profile, with upper-respiratory-tract infection and hypertension occurring most commonly and transient renal-related events detected less frequently [87].

Data produced in the lesinurad dossier have led the European Medicines Agency [EMA] to contraindicate the administration of lesinurad monotherapy [88]. However, its use has been approved at a daily dose of $200 \mathrm{mg}$ as an add-on therapy for patients who have 
had an inadequate response to the maximum tolerated doses of XOI, closely monitoring the renal function. In effect, lesinurad treatment has to be stopped if the serum creatinine levels increase more than two times the pre-treatment values or exceed $4.0 \mathrm{mg} / \mathrm{dL}$. Finally, lesinurad is not recommended for patients with uncontrolled hypertension, unstable angina, recent myocardial infarction, or New York Heart Association [NYHA] class III or IV heart failure [89].

\subsection{Arhalofenate}

Arhalofenate inhibits the proximal tubular UA reabsorption by interacting with OAT4 and URAT2. Moreover, it reduces the urate-crystal stimulated release of IL- $\$$ by modulating the peroxisome proliferator-activated receptor [PPAR] gamma pathway [90].

Arhalofenate is the first urate-lowering antiflare treatment, decreasing at a dosage of $800 \mathrm{mg}$ gout flares compared with allopurinol $300 \mathrm{mg}$, without background colchicine, and with a similar incidence of treatment-emergent adverse events among the active treated groups [91]. In particular, arhalofenate might be relevant in the management of gout in the elderly, since they are often unable to tolerate long-term colchicine for flare prophylaxis and frequently have contraindications to corticosteroids and non-steroidal anti-inflammatory drugs [92]. However, arhalofenate safety and the efficacy have not just been tested in renal impairment. Moreover, allopurinol has been demonstrated to ensure a greater SUA reduction than arhalofenate, whose antiflare and uricosuric activities, of consequence, offer more promising perspectives in a combination regimen with an XOI [65]. In fact, a 12-week open-label phase 2 study has shown that $800 \mathrm{mg}$ arhalofenate coadministered with $40 \mathrm{mg}$ or $80 \mathrm{mg}$ febuxostat exerts a more pronounced effect on SUA, with no reported deaths nor serious adverse events and no clinically relevant increase in serum creatinine [93].

Arhalofenate is currently in phase III clinical trials for the treatment of gout as add-on therapy to febuxostat. It had reached phase II/III clinical trials for the treatment of type 2 diabetes, but it was discontinued.

\subsection{Verinurad}

Verinurad is a high affinity and selective URAT1 inhibitor currently in development for the treatment of gout and asymptomatic hyperuricemia. This compound is one of the most potent URAT1 inhibitors yet identified and is highly specific for URAT1, with greater than 100-fold potency for URAT1 compared to the other transporters. In vivo, a single dose of verinurad $40 \mathrm{mg}$ has demonstrated to lower SUA by up to $62 \%$ whereas multiple doses of verinurad $10 \mathrm{mg}$ have reached a reduction in SUA levels approximately of $61 \%$, being well tolerated at all doses and with no serious adverse events nor significant laboratory or ECG abnormalities reported [94]. Moreover, in coadministration with allopurinol $300 \mathrm{mg}$, verinurad (2.5-20 mg) has been shown to produce a dose-dependent decrease in SUA, with no instances of serum creatinine elevation [95].

The high potency of verinurad has favorably provided the opportunity to more completely define the molecular interaction of URAT1 with its inhibitors. A URAT1 binding assay using radiolabeled verinurad has revealed that distinct URAT1 inhibitors benzbromarone, sulfinpyrazone, and probenecid all inhibit verinurad binding via a competitive mechanism [96].

The efficacy and safety of verinurad has been recently evaluated in two phase II placebo-controlled clinical trials enrolling patients with gout or asymptomatic hyperuricemia. Even though verinurad monotherapy has resulted in sustained reductions in UA, several renal adverse events occurred [97].

\subsection{Pegloticase}

Pegloticase is a recombinant, pegylated mammalian uricase whose efficacy and safety have been tested in some clinical trials, where it has demonstrated to deeply lower serum urate, resolve tophi, reduce tender and swollen joint counts, decrease pain, and improve both patients' global assessments and quality of life. Post hoc analyses of clinical results 
also indicated that chronic refractory gout patients not achieving sustained urate-lowering still have significant clinical benefits with pegloticase treatment [98]. Pegloticase also significantly decreases blood pressure in patients with chronic refractory gout but has no significant effect on renal function [99]. The major limitation of pegloticase is immunogenicity and the emergence of anti-drug antibodies that result in increased drug clearance, loss of efficacy, and infusion reactions, which can be prevented by the concomitant administration of immunosuppressant like methotrexate [100]. Furthermore, pegloticase is contraindicated in individuals with glucose-6-phosphate dehydrogenase (G6PD) deficiency [101]. For this reason, individuals at risk of this affection should undergo a prospective screening before starting treatment, to minimize the occurrence of pegloticase-related hemolytic anemia.

\subsection{Other Uricosuric Drugs}

There are drugs, which have not been specifically approved for use in gout, but with secondary uricosuric effects based on their pharmacodynamics. These drugs may be considered for treatment, especially in patients with comorbidities, which however would require these drugs.

The current assumption of hypouricemic effect following treatment with sodiumglucose co-transporter 2 [SGLT2] inhibitors is that glycosuria boosts excretion of UA in the urine. Actually, SUA reduction may be brought by a uricosuric effect secondary to glycosuria since hypouricemia and hyperuricosuria have been observed in subjects with familial renal glycosuria [102] hyperglycemic glycosuric type 1 diabetic patients, and euglycemic glycosuric type 1 diabetic patients following SGLT2 inhibition [103]. In vitro studies and clinical evidence have suggested that increased glucose concentration by gliflozins might carry out an increased efflux of UA into the lumen through GLUT9 in the proximal tubule [104].

The medications whose secondary effects might constitute a potential hyperuricemic treatment also include fenofibrate, a lipid-lowering drug activating intranuclear PPAR gamma whose metabolite fenofibric acid increases clearance of hypoxanthine and xanthine [105], and losartan, a unique angiotensin II receptor antagonist that inhibits renal tubular UA reabsorption increasing its urinary excretion. Both these drugs mainly target URAT1 $[106,107]$. Recently, the FIELD trial—which has been carried out on 9795 type 2 diabetic patients randomized to receive fenofibrate $200 \mathrm{mg}$ /day or matching placebo for 5 years-has demonstrated that fenofibrate lowers SUA concentrations by up to $20 \%$ and almost halves first on-study gout events over the 5 years of treatment [108].

It is thought that also the ascorbic acid (vitamin C) might act as a uricosuric, inhibiting the UA reabsorption by URAT1 and playing a role in enhancing UA elimination [109]. In vitro, salicylate/salicyclic acid and indomethacin also inhibit the UA uptake by URAT1 [110]. By the way, a meta-analysis of 13 randomized controlled clinical studies have revealed that daily doses of $500 \mathrm{mg}$ may reduce SUA levels and doses of $>1000 \mathrm{mg}$ /daily may even reduce the risk of developing gout [58].

\section{Discussion}

As well as several risk factors, including some medications, alcohol consumption, kidney disease, high blood pressure, hypothyroidism, obesity, are associated with an elevated risk of developing hyperuricemia, hyperuricemia seems to be an independent risk factor for the development of gout, but also coronary artery disease, CKD, type 2 diabetes mellitus, hypertension, atrial fibrillation and heart failure [111]. For this reason, optimizing SUA levels is increasingly a public health priority. In fact, SUA improvement could lead to a reduction in the risk of cardiovascular and renal events. In particular, a metaanalysis pooling data from 16 RCTs and including overall 1211 CKD patients, has recently shown that SUA-lowering therapy produces a 55\% relative risk [RR] reduction $(p<0.001)$ for kidney failure events, and even a $60 \%$ RR reduction $(p<0.001)$ for cardiovascular events [112]. 
Today there is no clear evidence that lifestyle modification might be effective in decreasing SUA levels: insofar as a low-energy Mediterranean diet aimed at achieving optimal body weight seems reasonably the best approach [113]. Single nutrients and food have been associated with impaired or improved SUA levels, but definite data are yet lacking. However, in most of the cases, diet is not sufficient to optimize SUA level and a specific treatment is needed. The available urate-lowering drugs have very different efficacy and, even more, tolerability/safety profile. They can be easily grouped by mechanism of SUA decrease: XOIs reduce urate production, while uricosuric drugs (i.e., probenecid, benzbromarone, sulfinpyrazone, and lesinurad) improve SUA renal excretion by inhibiting its reabsorption. Another strategy for enhancing UA excretion consists in the addition of exogenous forms of urate oxidase which are not expressed in humans Urate oxidase breaks down UA to 5-hydroxyisourate, which is then spontaneously degraded to allantoin and more readily excreted through the kidneys because of its 5-10 folds greater solubility [114]. The final effect is obviously a significant reduction in UA [115].

Injectable uricases enzymatically degrade UA to allantoin despite a relevant SUA lowering effect $[95,116,117]$. Recombinant urate oxidases (rasburicase, pegloticase) are not good candidates for chronic hyperuricemia treatment, because of the high cost and a large number of side effects and contraindications [118].

The main pharmacological and clinical characteristics of UA-lowering drugs are resumed in Table 1. 
Table 1. Main pharmacological and clinical characteristics of the available serum uric acid lowering drugs.

\begin{tabular}{|c|c|c|c|c|c|c|c|}
\hline & Drug & $\begin{array}{c}\text { Oral } \\
\text { Bioavailability }\end{array}$ & $\begin{array}{l}\text { Protein } \\
\text { Binding }\end{array}$ & Metabolism & $\begin{array}{l}\text { Biological } \\
\text { Half-Life }\end{array}$ & $\begin{array}{l}\text { Degree of Uric } \\
\text { Acid Reduction }\end{array}$ & $\begin{array}{c}\text { Main Recorded Treatment-Emergent } \\
\text { Adverse Events }\end{array}$ \\
\hline \multirow{3}{*}{$\begin{array}{c}\text { Xantine } \\
\text { Oxidase } \\
\text { Inhibitors [15] }\end{array}$} & $\begin{array}{l}\text { Allopurinol } \\
\left(\mathrm{C}_{5} \mathrm{H}_{4} \mathrm{~N}_{4} \mathrm{O}\right)\end{array}$ & $78 \pm 20 \%$ & Negligible & $\begin{array}{l}\text { Liver ( } 80 \% \text { oxipurinol, } 10 \% \\
\text { allopurinol ribosides) }\end{array}$ & $\begin{array}{l}2-3 \mathrm{~h} \\
\text { (oxipurinol } \\
14-30 \mathrm{~h} \text { ) }\end{array}$ & $2.5 \%$ to $23.6 \%$ & $\begin{array}{l}\text { Gastrointestinal distress, allopurinol } \\
\text { hypersensitivity syndrome, skin rash, } \\
\text { intestinal nephritis, hepatitis, } \\
\text { eosinophilia }\end{array}$ \\
\hline & $\begin{array}{c}\text { Febuxostat } \\
\left(\mathrm{C}_{16} \mathrm{H}_{16} \mathrm{~N}_{2} \mathrm{O}_{3} \mathrm{~S}\right)\end{array}$ & $>80 \%$ & $99 \%$ & $\begin{array}{c}\text { Liver (25-45\% unchanged, } \\
22-44 \% \text { febuxostat } \\
\text { acylglucuronide) }\end{array}$ & $5-8 \mathrm{~h}$ & $40 \%$ to $56 \%$ & $\begin{array}{l}\text { Muscle pain, gastrointestinal disorders, } \\
\text { elevation in liver enzymes }\end{array}$ \\
\hline & $\begin{array}{l}\text { Topiroxostat } \\
\left(\mathrm{C}_{13} \mathrm{H}_{8} \mathrm{~N}_{6}\right)\end{array}$ & $80 \%$ & $>92 \%$ & $\begin{array}{c}\text { Liver }(35.8 \% \text { 2-hydroxy } \\
\text { topiroxostat, } 4.8 \% \text { topiroxostat } \\
\text { N-oxide, } 43.3 \% \\
\text { N1-glucolonide, } 16.1 \% \\
\text { gluculonide) }\end{array}$ & $4.5-7.5 \mathrm{~h}$ & $45.38 \pm 21.8 \%$ & Elevation in liver enzymes, polyarthritis \\
\hline \multirow{4}{*}{$\begin{array}{l}\text { Uricosurics } \\
\quad[119]\end{array}$} & $\begin{array}{l}\text { Benzbromarone } \\
\left(\mathrm{C}_{17} \mathrm{H}_{12} \mathrm{Br}_{2} \mathrm{O}_{3}\right)\end{array}$ & $50 \%$ & $>99 \%$ & $\begin{array}{c}\text { Liver } \\
\text { (6-hydroxybenzbromarone, } \\
\text { 1'-hydroxybenzbromarone) }\end{array}$ & $4-17 \mathrm{~h}$ & $54 \%$ to $63 \%$ & Hepatotoxicity \\
\hline & $\begin{array}{c}\text { Lesinurad } \\
\left(\mathrm{C}_{17} \mathrm{H}_{14} \mathrm{BrN}_{3} \mathrm{O}_{2} \mathrm{~S}\right)\end{array}$ & $>90 \%$ & $>98 \%$ & $\begin{array}{l}\text { 65\% Liver (Hydroxylated } \\
\text { lesinurad, epoxide lesinurad), } \\
\text { 35\% Kidney (unchanged) }\end{array}$ & $9-10 \mathrm{~h}$ & $23 \%$ to $35 \%$ & $\begin{array}{l}\text { Fatal cardiovascular events, } \\
\text { nephrotoxicity, }\end{array}$ \\
\hline & $\begin{array}{c}\text { Arhalofenate } \\
\left(\mathrm{C}_{19} \mathrm{H}_{17} \mathrm{ClF}_{3} \mathrm{NO}_{4}\right)\end{array}$ & $>90$ & $>90$ & Liver (unclear) & $\sim 50 \mathrm{~h}$ & $12.5 \%$ to $16.5 \%$ & $\begin{array}{l}\text { Increase in creatine kinase, kidney } \\
\text { stones, angioedema, peripheral } \\
\text { neuropathy }\end{array}$ \\
\hline & $\begin{array}{c}\text { Verinurad } \\
\left(\mathrm{C}_{20} \mathrm{H}_{16} \mathrm{~N}_{2} \mathrm{O}_{2} \mathrm{~S}\right)\end{array}$ & $>90$ & $>90$ & $\begin{array}{l}\text { Liver (30\% unchanged, 32\% } \\
\text { acylglucuronide M1 and 30\% } \\
\text { M8 n-oxide acyglucuronide } 4 \text { ) }\end{array}$ & $\sim 30 \mathrm{~h}$ & $52 \%$ to $82 \%$ & $\begin{array}{l}\text { Renal failure and increase in creatinine, } \\
\text { gastrointestinal disorders }\end{array}$ \\
\hline $\begin{array}{c}\text { Drugs } \\
\text { increasing } \\
\text { SUA removal } \\
{[100]}\end{array}$ & $\begin{array}{c}\text { Peglotidase } \\
\left(\mathrm{C}_{1549} \mathrm{H}_{2430} \mathrm{~N}_{408} \mathrm{O}_{448} \mathrm{~S}_{8}\right)\end{array}$ & $\begin{array}{l}\text { Intravenous } \\
\text { injection }\end{array}$ & 0 & Unclear & $6.4-13.8$ days & $83 \%$ & $\begin{array}{l}\text { Infusion-related reactions, vomiting, } \\
\text { dyspnea, headache, urticaria, acute } \\
\text { gout attacks, changes in blood pressure, } \\
\text { methemoglobinemia }\end{array}$ \\
\hline
\end{tabular}


In general, treatment persistence is a key factor for a positive clinical outcome throughout treatment for hyperuricemia. However, a large meta-analysis pooling data from 24 clinical studies showed that medication adherence to urate-lowering therapy among gout patients is poor, suggesting more attention is also needed from clinicians [120]. Moreover, considering the burden of cardiovascular risk connected to hyperuricemia, the use of lipid-lowering and antihypertensive drugs (e.g., losartan and fenofibrate) being able to improve SUA levels is highly recommendable, insofar as this approach has not just been clearly demonstrated to reduce the SUA-related risk in humans. This approach should be even more rigorous in patients with diabetes since the use of SGLT2 inhibitors rather than other hypoglycemic medications resulted in SUA reduction by up to $-0.63 \mathrm{mg} / \mathrm{dL}$ [121]. Drugs impairing SUA levels (e.g., old-generation beta-blockers [122] and highly-dosed thiazides [123]) instead should be replaced with different antihypertensive drugs with neutral metabolic effects. Finally, considering the need for chronic treatment the choice of an SUAlowering drug should be oriented by consideration about its safety and tolerability [124] other than the positive effect on kidney and cardiovascular outcomes.

Main clinical indications of the available serum uric acid lowering drugs are resumed in Table 2. Compared with other medical fields, the panel of SUA lowering drugs is supported by a relatively large and good quality evidence. 
Table 2. Main clinical indications and characteristics of the available serum uric acid lowering drugs.

\begin{tabular}{|c|c|c|c|c|c|c|c|c|}
\hline & Drug & $\begin{array}{l}\text { Data Available from } \\
\text { Large Clinical Trials } \\
\text { (>10,000 Enrolled } \\
\text { Participants Overall) }\end{array}$ & Current State of Drug Approval & $\begin{array}{l}\text { Main } \\
\text { Therapy }\end{array}$ & $\begin{array}{l}\text { Add-on } \\
\text { Therapy }\end{array}$ & $\begin{array}{l}\text { Suitable for } \\
\text { Use in Gout }\end{array}$ & $\begin{array}{c}\text { Suitable for Use } \\
\text { in Asymptomatic } \\
\text { Hyperuricemic } \\
\text { Subjects }\end{array}$ & $\begin{array}{c}\text { Safely } \\
\text { Administered } \\
\text { in Renal } \\
\text { Failure }\end{array}$ \\
\hline \multirow{3}{*}{$\begin{array}{l}\text { Xantine-Oxidase } \\
\text { inhibitors [15] }\end{array}$} & Allopurinol & Yes & Approved by EMA and FDA & Yes & No & No & Yes & No \\
\hline & Febuxostat & Yes & Approved by EMA and FDA & Yes & No & Yes & No & Yes \\
\hline & Topiroxostat & No & Approved by Japanese authorities only & Yes & No & Yes & Yes & Yes \\
\hline \multirow{5}{*}{$\begin{array}{c}\text { Primarily } \\
\text { uricosuric drugs } \\
\text { [117] }\end{array}$} & Arhalofenate & No & Drug in development & No & Yes & Yes & No & NA \\
\hline & Benzbromarone & No & Withdrawn for safety reasons & No & Yes & Yes & Yes & No \\
\hline & Lesinurad & No & Conditionally approved by EMA and FDA & No & Yes & Yes & Yes & No \\
\hline & Probenecid & Yes & Approved by EMA and FDA & Yes & Yes & Yes & Yes & No \\
\hline & Verinurad & No & Not approved & No & Yes & Yes & Yes & NA \\
\hline \multirow{2}{*}{$\begin{array}{l}\text { Other uricosuric } \\
\text { drugs [107] }\end{array}$} & Fenofibrate & Yes & Approved by EMA and FDA ${ }^{\circ}$ & No & Yes & NA & NA & No \\
\hline & Losartan & Yes & Approved by EMA and FDA ${ }^{\circ}$ & No & Yes & NA & NA & Yes \\
\hline
\end{tabular}

EMA = European Medicines Agency; FDA = Food and Drug Administration; NA = Not Available ${ }^{\circ}$ Approved for indications different than hyperuricemia and/or gout. 


\section{Conclusions}

Xanthine oxidase inhibitors remain the safest and most effective SUA lowering drug for chronic treatment, while the efficacy of uricosuric agents is strongly modulated by pharmacogenetics. In particular, the $2020 \mathrm{ACR}$ guidelines recommend the use of allopurinol as the preferred first-line urate-lowering therapy for all patients, including those with CKD, due to the respective cost and potential cardiovascular safety concerns recently emerged with febuxostat [125]. In patients with contraindication to allopurinol, febuxostat should be preferred to uricosuric drugs.

New emergent medications seem to be particularly effective in the acute management of refractory hyperuricemia, but their use is supported by a relatively small number of clinical trials. For this reason, further well-designed, long-term clinical trials are needed to deeper investigate their efficacy and safety profile.

Author Contributions: Conceptualization, A.F.G.C. and C.B.; methodology, A.F.G.C. and F.F.; investigation, A.F.G.C. and F.F.; writing-original draft preparation, A.F.G.C. and F.F.; writing-review and editing, M.K. and C.B.; supervision, M.K. and C.B.; project administration, A.F.G.C. Authorship must be limited to those who have contributed substantially to the work reported. All authors have read and agreed to the published version of the manuscript.

Funding: This research received no external funding.

Institutional Review Board Statement: Not applicable.

Informed Consent Statement: Not applicable.

Data Availability Statement: Not applicable.

Conflicts of Interest: The authors declare no direct conflict of interest in the publication of this paper.

\section{References}

1. Oda, M.; Satta, Y.; Takenaka, O.; Takahata, N. Loss of urate oxidase activity in hominoids and its evolutionary implications. Mol. Biol. Evol. 2002, 19, 640-653. [CrossRef]

2. Jin, M.; Yang, F.; Yang, I.; Yin, Y.; Luo, J.J.; Wang, H.; Yang, X.F. Uric acid, hyperuricemia and vascular diseases. Front. Biosci. 2012, 17, 656-669. [CrossRef] [PubMed]

3. Cicero, A.F.; Rosticci, M.; Fogacci, F.; Grandi, E.; D’Addato, S.; Borghi, C.; Brisighella Heart Study Group. High serum uric acid is associated to poorly controlled blood pressure and higher arterial stiffness in hypertensive subjects. Eur. J. Intern. Med. 2017, 37, 38-42. [CrossRef] [PubMed]

4. Pascart, T.; Lioté, F. Gout: State of the art after a decade of developments. Rheumatology 2019, 58, 27-44. [CrossRef] [PubMed]

5. Katsiki, N.; Karagiannis, A.; Athyros, V.G.; Mikhailidis, D.P. Hyperuricaemia: More than just a cause of gout? J. Cardiovasc. Med. 2013, 14, 397-402. [CrossRef] [PubMed]

6. Galassi, F.M.; Borghi, C. A brief history of uric acid: From gout to cardiovascular risk factor. Eur. J. Intern. Med. 2015, 26, 373. [CrossRef] [PubMed]

7. Cicero, A.F.G.; Fogacci, F.; Giovannini, M.; Grandi, E.; Rosticci, M.; D'Addato, S.; Borghi, C. Serum uric acid predicts incident metabolic syndrome in the elderly in an analysis of the Brisighella Heart Study. Sci. Rep. 2018, 8, 11529. [CrossRef]

8. Virdis, A.; Masi, S.; Casiglia, E.; Tikhonoff, V.; Cicero, A.F.G.; Ungar, A.; Rivasi, G.; Salvetti, M.; Barbagallo, C.M.; Bombelli, M.; et al. Identification of the Uric Acid Thresholds Predicting an Increased Total and Cardiovascular Mortality Over 20 Years. Hypertension 2020, 75, 302-308. [CrossRef]

9. Muiesan, M.L.; Salvetti, M.; Virdis, A.; Masi, S.; Casiglia, E.; Tikhonoff, V.; Barbagallo, C.M.; Bombelli, M.; Cicero, A.F.G.; Cirillo, M.; et al. Serum uric acid, predicts heart failure in a large Italian cohort: Search for a cut-off value the URic acid Right for heArt Health study. J. Hypertens. 2020, 39, 62-69. [CrossRef]

10. Casiglia, E.; Tikhonoff, V.; Virdis, A.; Masi, S.; Barbagallo, C.M.; Bombelli, M.; Bruno, B.; Cicero, A.F.G.; Cirillo, M.; Cirillo, P.; et al. Serum uric acid and fatal myocardial infarction: Detection of prognostic cut-off values: The URRAH (Uric Acid Right for Heart Health) study. J. Hypertens. 2020, 38, 412-419. [CrossRef]

11. Kaya, M.G.; Uyarel, H.; Akpek, M.; Kalay, N.; Ergelen, M.; Ayhan, E.; Isik, T.; Cicek, G.; Elcik, D.; Sahin, O.; et al. Prognostic value of uric acid in patients with ST-elevated myocardial infarction undergoing primary coronary intervention. Am. J. Cardiol. 2012, 109, 486-491. [CrossRef] [PubMed]

12. Mandurino-Mirizzi, A.; Cornara, S.; Somaschini, A.; Demarchi, A.; Galazzi, M.; Puccio, S.; Montalto, C.; Crimi, G.; Ferlini, M.; Camporotondo, R.; et al. Elevated serum uric acid is associated with a greater inflammatory response and with short- and long-term mortality in patients with ST-segment elevation myocardial infarction undergoing primary percutaneous coronary intervention. Nutr. Metab. Cardiovasc. Dis. 2020, in press. [CrossRef] [PubMed] 
13. Borghi, C. Uric acid as a cross-over between rheumatology and cardiovascular disease. Curr. Med. Res. Opin. 2013, $29,1-2$. [CrossRef] [PubMed]

14. Borghi, C. The management of hyperuricemia: Back to the pathophysiology of uric acid. Curr. Med. Res. Opin. 2017, 33, 1-4. [CrossRef] [PubMed]

15. Cicero, A.F.G.; Fogacci, F.; Cincione, R.I.; Tocci, G.; Borghi, C. Clinical Effects of Xanthine Oxidase Inhibitors in Hyperuricemic Patients. Med. Princ. Pract. 2020. [CrossRef]

16. Bredemeier, M.; Lopes, L.M.; Eisenreich, M.A.; Hickmann, S.; Bongiorno, G.K.; d'Avila, R.; Morsch, A.L.B.; da Silva Stein, F.; Campos, G.G.D. Xanthine oxidase inhibitors for prevention of cardiovascular events: A systematic review and meta-analysis of randomized controlled trials. BMC Cardiovasc. Disord. 2018, 18, 24. [CrossRef]

17. Okafor, O.N.; Farrington, K.; Gorog, D.A. Allopurinol as a therapeutic option in cardiovascular disease. Pharmacol. Ther. 2017, 172, 139-150. [CrossRef]

18. Bove, M.; Cicero, A.F.; Veronesi, M.; Borghi, C. An evidence-based review on urate-lowering treatments: Implications for optimal treatment of chronic hyperuricemia. Vasc. Health Risk Manag. 2017, 13, 23-28. [CrossRef]

19. Day, R.O.; Graham, G.G.; Hicks, M.; McLachlan, A.J.; Stocker, S.L.; Williams, K.M. Clinical pharmacokinetics and pharmacodynamics of allopurinol and oxypurinol. Clin. Pharm. 2007, 46, 623-644. [CrossRef]

20. Allopurinol Tablet. Accord Healthcare Inc. Available online: http://dailymed.nlm.nih.gov/dailymed/lookup.cfm?setid=682dd8 b8-fc6e-47c5-95b7-2d7ad96b750 (accessed on 9 October 2019).

21. Cicero, A.F.G.; Pirro, M.; Watts, G.F.; Mikhailidis, D.P.; Banach, M.; Sahebkar, A. Effects of Allopurinol on Endothelial Function: A Systematic Review and Meta-Analysis of Randomized Placebo-Controlled Trials. Drugs 2018, 78, 99-109. [CrossRef]

22. Siu, Y.P.; Leung, K.T.; Tong, M.K.; Kwan, T.H. Use of allopurinol in slowing the progression of renal disease through its ability to lower serum uric acid level. Am. J. Kidney Dis. 2006, 47, 51-59. [CrossRef] [PubMed]

23. Goicoechea, M.; de Vinuesa, S.G.; Verdalles, U.; Ruiz-Caro, C.; Ampuero, J.; Rincón, A.; Arroyo, D.; Luño, J. Effect of allopurinol in chronic kidney disease progression and cardiovascular risk. Clin. J. Am. Soc. Nephrol. 2010, 5, 1388-1393. [CrossRef] [PubMed]

24. Pea, F. Pharmacology of drugs for hyperuricemia: Mechanisms, kinetics and interactions. Contrib. Nephrol. 2005, 147, 35-46. [PubMed]

25. Chao, J.; Terkeltaub, R. A critical reappraisal of allopurinol dosing, safety, and efficacy for hyperuricemia in gout. Curr. Rheumatol. Rep. 2009, 11, 135-140. [CrossRef] [PubMed]

26. Stamp, L.K.; Taylor, W.J.; Jones, P.B.; Dockerty, J.L.; Drake, J.; Frampton, C.; Dalbeth, N. Starting dose is a risk factor for allopurinol hypersensitivity syndrome: A proposed safe starting dose of allopurinol. Arthritis Rheum. 2012, 64, 2529-2536. [CrossRef] [PubMed]

27. Chung, Y.; Stocker, S.L.; Graham, G.G.; Day, R.O. Optimizing therapy with allopurinol: Factors limiting hypouricemic efficacy. Am. J. Med. Sci. 2008, 335, 219-226. [CrossRef]

28. Hung, S.I.; Chung, W.H.; Liou, L.B.; Chu, C.C.; Lin, M.; Huang, H.P.; Lin, Y.L.; Lan, J.L.; Yang, L.C.; Hong, H.S.; et al. HLA-B5801 allel as a genetic marker for severe cutaneous adverse reactions caused by allopurinol. Proc. Nat. Acad. Sci. USA 2005, 102, 4134-4139. [CrossRef]

29. Panel on Antiretroviral Guidelines for Adults and Adolescents. Guidelines for the Use of Antiretroviral Agents in HIV-1Infected Adults and Adolescents. Department of Health and Human Services. Available online: http://www.aidsinfo.nih.gov/ ContentFiles/AdultandAdolescentGL.pdf (accessed on 14 April 2019).

30. Allopurinol Oral Tablets; Northstar Rx LLC: Memphis, TN, USA, 2015.

31. Stamp, L.K.; O’Donnell, J.L.; Zhang, M.; James, J.; Frampton, C.; Barclay, M.L.; Chapman, P.T. Using allopurinol above the dose based on creatinine clearance is effective and safe in patients with chronic gout, including those with renal impairment. Arthritis Rheum. 2011, 63, 412-421. [CrossRef]

32. Pascual, E.; Sivera, F.; Yasothan, U.; Kirkpatrick, P. Febuxostat. Nat. Rev. Drug Discov. 2009, 8, 191-192. [CrossRef]

33. Becker, M.A.; Schumacher, H.R., Jr.; Wortmann, R.L.; MacDonald, P.A.; Eustace, D.; Palo, W.A.; Streit, J.; Joseph-Ridge, N. Febuxostat compared with allopurinol in patients with hyperuricemia and gout. N. Engl. J. Med. 2005, 353, 2450-2461. [CrossRef]

34. Schumacher, H.R., Jr.; Becker, M.A.; Wortmann, R.L.; Macdonald, P.A.; Hunt, B.; Streit, J.; Lademacher, C.; Joseph-Ridge, N. Effects of febuxostat versus allopurinol and placebo in reducing serum urate in subjects with hyperuricemia and gout: A 28-week, phase III, randomized, double-blind, parallel-group trial. Arthritis Rheum. 2008, 59, 1540-1548. [CrossRef]

35. Malik, U.Z.; Hundley, N.J.; Romero, G.; Radi, R.; Freeman, B.A.; Tarpey, M.M.; Kelley, E.E. Febuxostat inhibition of endothelialbound XO: Implications for targeting vascular ROS production. Free Radic. Biol. Med. 2011, 51, 179-184. [CrossRef]

36. Tausche, A.K.; Christoph, M.; Forkmann, M.; Richter, U.; Kopprasch, S.; Bielitz, C.; Aringer, M.; Wunderlich, C. As compared to allopurinol, urate-lowering therapy with febuxostat has superior effects on oxidative stress and pulse wave velocity in patients with severe chronic tophaceous gout. Rheumatol. Int. 2014, 34, 101-109. [CrossRef]

37. Hays, A.G.; Iantorno, M.; Schär, M.; Lai, S.; Czarny, M.; Breton, E.; Palmer, R.N.; Whelton, A.; Weiss, R.G.; Gerstenblith, G. The influence of febuxostat on coronary artery endothelial dysfunction in patients with coronary artery disease: A phase 4 randomized, placebo-controlled, double-blind, crossover trial. Am. Heart J. 2018, 197, 85-93. [CrossRef] [PubMed]

38. Uloric (Febuxostat) Drug Label Available on the Daily Med Website. Available online: http://dailymed.nlm.nih.gov/dailymed/ lookup.cfm?setid=54de10ef-fe5f-4930-b91d-6bbb04c664bd (accessed on 9 October 2019). 
39. FitzGerald, J.D.; Dalbeth, N.; Mikuls, T.; Brignardello-Petersen, R.; Guyatt, G.; Abeles, A.M.; Gelber, A.C.; Harrold, L.R.; Khanna, D.; King, C.; et al. American College of Rheumatology Guideline for the Management of Gout. Arthritis Rheumatol. 2020, 72, 879-895. [CrossRef] [PubMed]

40. Uloric; Takeda Pharmaceuticals America, Inc.: Deerfield, IL, USA, 2013.

41. Liu, C.W.; Chang, W.C.; Lee, C.C.; Shau, W.Y.; Hsu, F.S.; Wang, M.L.; Chen, T.C.; Lo, C.; Hwang, J.J. The net clinical benefits of febuxostat versus allopurinol in patients with gout or asymptomatic hyperuricemia-A systematic review and meta-analysis. Nutr. Metab. Cardiovasc. Dis. 2019, 29, 1011-1022. [CrossRef] [PubMed]

42. Borghi, C.; Perez-Ruiz, F. Urate lowering therapies in the treatment of gout: A systematic review and meta-analysis. Eur. Rev. Med. Pharm. Sci. 2016, 20, 983-992.

43. Kim, S.; Kim, H.J.; Ahn, H.S.; Oh, S.W.; Han, K.H.; Um, T.H.; Cho, C.R.; Han, S.Y. Renoprotective effects of febuxostat compared with allopurinol in patients with hyperuricemia: A systematic review and meta-analysis. Kidney Res. Clin. Pract. 2017, 36, 274-281. [CrossRef]

44. Baek, C.H.; Kim, H.; Yang, W.S.; Han, D.J.; Park, S.K. Efficacy and Safety of Febuxostat in Kidney Transplant Patients. Exp. Clin. Transplant. 2018, 16, 401-406.

45. Richette, P.; Doherty, M.; Pascual, E.; Barskova, V.; Becce, F.; Castañeda-Sanabria, J.; Coyfish, M.; Guillo, S.; Jansen, T.L.; Janssens, H.; et al. 2016 updated EULAR evidence-based recommendations for the management of gout. Ann. Rheum. Dis. 2017, 76, 29-42. [CrossRef]

46. Qaseem, A.; Harris, R.P.; Forciea, M.A. For the clinical guidelines committee of the American College of Physicians. Management of acute and recurrent gout: A clinical practice guideline from the American College of Physicians. Ann. Intern. Med. 2017, 166, 58-68. [CrossRef] [PubMed]

47. White, W.B.; Saag, K.G.; Becker, M.A.; Borer, J.S.; Gorelick, P.B.; Whelton, A.; Hunt, B.; Castillo, M.; Gunawardhana, L.; CARES Investigators. Cardiovascular Safety of Febuxostat or Allopurinol in Patients with Gout. N. Engl. J. Med. 2018, 378, 1200-1210. [CrossRef] [PubMed]

48. Mackenzie, I.S.; Ford, I.; Nuki, G.; Hallas, J.; Hawkey, C.J.; Webster, J.; Ralston, S.H.; Walters, M.; Robertson, M.; De Caterina, R.; et al. Long-term cardiovascular safety of febuxostat compared with allopurinol in patients with gout (FAST): A multicentre, prospective, randomised, open-label, non-inferiority trial. Lancet 2020, 396, 1745-1757. [CrossRef]

49. Hosoya, T.; Sasaki, T.; Ohashi, T. Clinical efficacy and safety of topiroxostat in Japanese hyperuricemic patients with or without gout: A randomized, double-blinded, controlled phase 2b study. Clin. Rheumatol. 2017, 36, 649-656. [CrossRef]

50. Nakamura, T.; Murase, T.; Nampei, M.; Morimoto, N.; Ashizawa, N.; Iwanaga, T.; Sakamoto, R. Effects of topiroxostat and febuxostat on urinary albumin excretion and plasma xanthine oxidoreductase activity in db/db mice. Eur. J. Pharm. 2016, 780, 224-231. [CrossRef]

51. Hosoya, T.; Ohno, I.; Nomura, S.; Hisatome, I.; Uchida, S.; Fujimori, S.; Yamamoto, T.; Hara, S. Effects of topiroxostat on the serum urate levels and urinary albumin excretion in hyperuricemic stage 3 chronic kidney disease patients with or without gout. Clin. Exp. Nephrol. 2014, 18, 876-884. [CrossRef]

52. Nagaoka, Y.; Tanaka, Y.; Yoshimoto, H.; Suzuki, R.; Ryu, K.; Ueda, M.; Akiyama, M.; Nagai, M.; Miyaoka, Y.; Kanda, E.; et al. The effect of small dose of topiroxostat on serum uric acid in patients receiving hemodialysis. Hemodial. Int. 2018, 22, 388-393. [CrossRef]

53. Kato, S.; Ando, M.; Mizukoshi, T.; Nagata, T.; Katsuno, T.; Kosugi, T.; Tsuboi, N.; Maruyama, S. Randomized control trial for the assessment of the anti-albuminuric effects of topiroxostat in hyperuricemic patients with diabetic nephropathy (the ETUDE study). Nagoya J. Med. Sci. 2016, 78, 135-142.

54. Lipkowitz, M.S. Regulation of uric acid excretion by the kidney. Curr. Rheumatol. Rep. 2012, 14, 179-188. [CrossRef]

55. Wright, A.F.; Rudan, I.; Hastie, N.D.; Campbell, H. A 'complexity' of urate transporters. Kidney Int. 2010, 78, 446-452. [CrossRef]

56. Reginato, A.M.; Mount, D.B.; Yang, I.; Choi, H.K. The genetics of hyperuricaemia and gout. Nat. Rev. Rheumatol. 2012, 8, 610-621. [CrossRef] [PubMed]

57. Shin, H.J.; Takeda, M.; Enomoto, A.; Fujimura, M.; Miyazaki, H.; Anzai, N.; Endou, H. Interactions of urate transporter URAT1 in human kidney with uricosuric drugs. Nephrology 2011, 16, 156-162. [CrossRef] [PubMed]

58. Enomoto, A.; Kimura, H.; Chairoungdua, A.; Shigeta, Y.; Jutabha, P.; Cha, S.H.; Hosoyamada, M.; Takeda, M.; Sekine, T.; Igarashi, T.; et al. Molecular identification of a renal urate anion exchanger that regulates blood urate levels. Nature 2002, 417, 447-452. [CrossRef] [PubMed]

59. Le, M.T.; Shafiu, M.; Mu, W.; Johnson, R.J. SLC2A9-A fructose transporter identified as a novel uric acid transporter. Nephrol. Dial. Transplant. 2008, 23, 2746-2749. [CrossRef]

60. Kolz, M.; Johnson, T.; Sanna, S.; Teumer, A.; Vitart, V.; Perola, M.; Mangino, M.; Albrecht, E.; Wallace, C.; Farrall, M.; et al. Meta-analysis of 28,141 individuals identifies common variants within five new loci that influence uric acid concentrations. PLoS Genet. 2009, 5, e1000504. [CrossRef]

61. Okada, Y.; Sim, X.; Go, M.J.; Wu, J.Y.; Gu, D.; Takeuchi, F.; Takahashi, A.; Maeda, S.; Tsunoda, T.; Chen, P.; et al. Meta-analysis identifies multiple loci associated with kidney function-related traits in east Asian populations. Nat. Genet. 2012, 44, 904-909. [CrossRef] 
62. Köttgen, A.; Albrecht, E.; Teumer, A.; Vitart, V.; Krumsiek, J.; Hundertmark, C.; Pistis, G.; Ruggiero, D.; O'Seaghdha, C.M.; Haller, T.; et al. Genome-wide association analyses identify 18 new loci associated with serum urate concentrations. Nat. Genet. 2013, 45, 145-154. [CrossRef]

63. Sato, M.; Iwanaga, T.; Mamada, H.; Ogihara, T.; Yabuuchi, H.; Maeda, T.; Tamai, I. Involvement of uric acid transporters in alteration of serum uric acid level by angiotensin II receptor blockers. Pharm. Res. 2008, 25, 639-646. [CrossRef]

64. Burckhardt, G.; Burckhardt, B.C. In vitro and in vivo evidence of the importance of organic anion transporters (OATs) in drug therapy. In Drug Transporters; Springer: Berlin/Heidelberg, Germany, 2011; pp. 29-104.

65. Pascart, T.; Richette, P. Current and future therapies for gout. Expert Opin. Pharm. 2017, 18, 1201-1211. [CrossRef]

66. Silverman, W.; Locovei, S.; Dahl, G. Probenecid, a gout remedy, inhibits pannexin 1 channels. Am. J. Physiol.-Cell Physiol. 2008, 295, C761-C767. [CrossRef]

67. Bach, M.H.; Simkin, P.A. Uricosuric drugs: The once and future therapy for hyperuricemia? Curr. Opin. Rheumatol. 2014, 26, 169-175. [CrossRef] [PubMed]

68. Cunningham, R.F.; Israili, Z.H.; Dayton, P.G. Clinical pharmacokinetics of probenecid. Clin. Pharm. 1981, 6, 135-151. [CrossRef] [PubMed]

69. American Geriatrics Society 2015 Beers Criteria Update Expert Panel. American Geriatrics Society 2015 updated Beers Criteria for potentially inappropriate medication use in older adults. J. Am. Geriatr. Soc. 2015, 63, 2227-2246. [CrossRef] [PubMed]

70. Kim, S.C.; Neogi, T.; Kang, E.H.; Liu, J.; Desai, R.J.; Zhang, M.; Solomon, D.H. Cardiovascular Risks of Probenecid Versus Allopurinol in Older Patients with Gout. J. Am. Coll. Cardiol. 2018, 71, 994-1004. [CrossRef]

71. Borgi, L.; McMullan, C.; Wohlhueter, A.; Curhan, G.C.; Fisher, N.D.; Forman, J.P. Effect of Uric Acid-Lowering Agents on Endothelial Function: A Randomized, Double-Blind, Placebo-Controlled Trial. Hypertension 2017, 69, 243-248. [CrossRef]

72. Probenecid Oral Tablets; Marlex Pharmaceuticals, Inc.: New Castle, DE, USA, 2012.

73. Probenecid and Colchicine Tablets; Rising Pharmaceuticals, Inc.: Allendale, NJ, USA, 2011.

74. Lee, M.H.; Graham, G.G.; Williams, K.M.; Day, R.O. A benefit-risk assessment of benzbromarone in the treatment of gout. Was its withdrawal from the market in the best interest of patients? Drug Saf. 2008, 31, 643-665. [CrossRef]

75. Ichida, K.; Hosoyamada, M.; Kimura, H.; Takeda, M.; Utsunomiya, Y.; Hosoya, T.; Endou, H. Urate transport via human PAH transporter hOAT1 and its gene structure. Kidney Int. 2003, 63, 143-155. [CrossRef]

76. Walter-Sack, I.; de Vries, J.X.; Ittensohn, A.; Kohlmeier, M.; Weber, E. Benzbromarone disposition and uricosuric action; evidence for hydroxilation instead of debromination to benzarone. Klin. Wochenschr. 1988, 66, 160-166. [CrossRef]

77. Chou, H.W.; Chiu, H.T.; Tsai, C.W.; Ting, I.W.; Yeh, H.C.; Huang, H.C.; Kuo, C.C.; CMUH Kidney Research Group. Comparative effectiveness of allopurinol, febuxostat and benzbromarone on renal function in chronic kidney disease patients with hyperuricemia: A 13-year inception cohort study. Nephrol. Dial. Transplant. 2018, 33, 1620-1627. [CrossRef]

78. Heel, R.C.; Brogden, R.N.; Speight, T.M.; Avery, G.S. Benzbromarone: A review of its pharmacological properties and therapeutic use in gout and hyperuricaemia. Drugs 1977, 14, 349-366. [CrossRef]

79. Robinson, P.C.; Dalbeth, N. Lesinurad for the treatment of hyperuricaemia in people with gout. Expert Opin. Pharm. 2017, 18, 1875-1881. [CrossRef] [PubMed]

80. Miner, J.N.; Tan, P.K.; Hyndman, D.; Liu, S.; Iverson, C.; Nanavati, P.; Hagerty, D.T.; Manhard, K.; Shen, Z.; Girardet, J.L.; et al. Lesinurad, a novel, oral compound for gout, acts to decrease serum uric acid through inhibition of urate transporters in the kidney. Arthritis Res. 2016, 18, 214-223. [CrossRef] [PubMed]

81. Gillen, M.; Yang, C.; Wilson, D.; Valdez, S.; Lee, C.; Kerr, B.; Shen, Z. Evaluation of Pharmacokinetic Interactions Between Lesinurad, a New Selective Urate Reabsorption Inhibitor, and CYP Enzyme Substrates Sildenafil, Amlodipine, Tolbutamide, and Repaglinide. Clin. Pharm. Drug Dev. 2017, 6, 363-376. [CrossRef] [PubMed]

82. Shen, Z.; Tieu, K.; Wilson, D.; Bucci, G.; Gillen, M.; Lee, C.; Kerr, B. Evaluation of Pharmacokinetic Interactions Between Lesinurad, a New Selective Urate Reabsorption Inhibitor, and Commonly Used Drugs for Gout Treatment. Clin. Pharm. Drug Dev. 2017, 6, 377-387. [CrossRef] [PubMed]

83. Tausche, A.K.; Alten, R.; Dalbeth, N.; Kopicko, J.; Fung, M.; Adler, S.; Bhakta, N.; Storgard, C.; Baumgartner, S.; Saag, K. Lesinurad monotherapy in gout patients intolerant to a xanthine oxidase inhibitor: A 6 month phase 3 clinical trial and extension study. Rheumatology 2017, 56, 2170-2178. [CrossRef] [PubMed]

84. Bardin, T.; Keenan, R.T.; Khanna, P.P.; Kopicko, J.; Fung, M.; Bhakta, N.; Adler, S.; Storgard, C.; Baumgartner, S.; So, A. Lesinurad in combination with allopurinol: A randomised, double-blind, placebo-controlled study in patients with gout with inadequate response to standard of care (the multinational CLEAR 2 study). Ann. Rheum. Dis. 2017, 76, 811-820. [CrossRef] [PubMed]

85. Saag, K.G.; Fitz-Patrick, D.; Kopicko, J.; Fung, M.; Bhakta, N.; Adler, S.; Storgard, C.; Baumgartner, S.; Becker, M.A. Lesinurad Combined With Allopurinol: A Randomized, Double-Blind, Placebo-Controlled Study in Gout Patients With an Inadequate Response to Standard-of-Care Allopurinol (a US-Based Study). Arthritis Rheumatol. 2017, 69, 203-212. [CrossRef]

86. Dalbeth, N.; Jones, G.; Terkeltaub, R.; Khanna, D.; Kopicko, J.; Bhakta, N.; Adler, S.; Fung, M.; Storgard, C.; Baumgartner, S.; et al. Lesinurad, a Selective Uric Acid Reabsorption Inhibitor, in Combination With Febuxostat in Patients with Tophaceous Gout: Findings of a Phase III Clinical Trial. Arthritis Rheumatol. 2017, 69, 1903-1913. [CrossRef]

87. Haber, S.L.; Fente, G.; Fenton, S.N.; Walker, E.P.; Weaver, B.M.; Cano, A.J.; Vu, K. Lesinurad: A Novel Agent for Management of Chronic Gout. Ann. Pharm. 2018, 52, 690-696. [CrossRef] 
88. European Medicines Agency. Zurampic EPAR Product Information. 2017. Available online: http://www.ema.europa.eu/ema/ index.jsp?curl=pages/medicines/human/medicines/003932/human_med_001963.jsp\&mid=WC0b01ac058001d124 (accessed on 25 October 2020).

89. Bardin, T.; Richette, P. Novel uricosurics. Rheumatology 2018, 57, i42-i46. [CrossRef]

90. Sattui, S.E.; Gaffo, A.L. Treatment of hyperuricemia in gout: Current therapeutic options, latest developments and clinical implications. Ther. Adv. Musculoskelet Dis. 2016, 8, 145-159. [CrossRef] [PubMed]

91. Poiley, J.; Steinberg, A.S.; Choi, Y.J.; Davis, C.S.; Martin, R.L.; McWherter, C.A.; Boudes, P.F. Arhalofenate Flare Study Investigators. A Randomized, Double-Blind, Active- and Placebo-Controlled Efficacy and Safety Study of Arhalofenate for Reducing Flare in Patients with Gout. Arthritis Rheumatol. 2016, 68, 2027-2034. [CrossRef]

92. Abhishek, A. Managing Gout Flares in the Elderly: Practical Considerations. Drugs Aging 2017, 34, 873-880. [CrossRef] [PubMed]

93. Steinberg, A.S.; Vince, B.D.; Choi, Y.J.; Martin, R.L.; McWherter, C.A.; Boudes, P.F. The Pharmacodynamics, Pharmacokinetics, and Safety of Arhalofenate in Combination with Febuxostat When Treating Hyperuricemia Associated with Gout. J. Rheumatol. 2017, 44, 374-379. [CrossRef] [PubMed]

94. Shen, Z.; Gillen, M.; Miner, J.N.; Bucci, G.; Wilson, D.M.; Hall, J.W. Pharmacokinetics, pharmacodynamics, and tolerability of verinurad, a selective uric acid reabsorption inhibitor, in healthy adult male subjects. Drug Des. Dev. Ther. 2017, 11, 2077-2086. [CrossRef]

95. Fleischmann, R.; Winkle, P.; Miner, J.N.; Yan, X.; Hicks, L.; Valdez, S.; Hall, J.; Liu, S.; Shen, Z.; Gillen, M.; et al. Pharmacodynamic and pharmacokinetic effects and safety of verinurad in combination with allopurinol in adults with gout: A phase IIa, open-label study. RMD Open 2018, 4, e000584. [CrossRef]

96. Tan, P.K.; Liu, S.; Gunic, E.; Miner, J.N. Discovery and characterization of verinurad, a potent and specific inhibitor of URAT1 for the treatment of hyperuricemia and gout. Sci. Rep. 2017, 7, 665. [CrossRef]

97. Fitz-Patrick, D.; Roberson, K.; Niwa, K.; Fujimura, T.; Mori, K.; Hall, J.; Yan, X.; Shen, Z.; Liu, S.; Ito, Y.; et al. Safety and efficacy of verinurad, a selective URAT1 inhibitor, for the treatment of patients with gout and/or asymptomatic hyperuricemia in the United States and Japan: Findings from two phase II trials. Mod. Rheumatol. 2019, 29, 1042-1052. [CrossRef]

98. Schlesinger, N.; Lipsky, P.E. Pegloticase treatment of chronic refractory gout: Update on efficacy and safety. In Seminars in Arthritis and Rheumatism; W.B. Saunders: Philadelphia, PA, USA, 2020; pp. S31-S38.

99. Johnson, R.J.; Choi, H.K.; Yeo, A.E.; Lipsky, P.E. Pegloticase Treatment Significantly Decreases Blood Pressure in Patients with Chronic Gout. Hypertension 2019, 74, 95-101. [CrossRef]

100. Botson, J.K.; Tesser, J.; Bennett, R.; Kenney, H.M.; Peloso, P.M.; Obermeyer, K.; LaMoreaux, B.; Weinblatt, M.E.; Peterson, J. Pegloticase in combination with methotrexate in patients with uncontrolled gout: A multicenter, open-label study (MIRROR). J. Rheumatol. 2020. [CrossRef]

101. Roberts, R.L.; Stamp, L.K. Pharmacogenetic considerations in the treatment of gout. Pharmacogenomics 2015, 16, 619-629. [CrossRef]

102. Aires, I.; Santos, A.R.; Pratas, J.; Nolasco, F.; Calado, J. Hypouricaemia and hype ruricosuria in familial renal glucosuria. Clin. Kidney J. 2013, 6, 523-525. [CrossRef] [PubMed]

103. Lytvyn, Y.; Škrtić, M.; Yang, G.K.; Yip, P.M.; Perkins, B.A.; Cherney, D.Z. Glycosuria mediated urinary uric acid excretion in patients with uncomplicated type 1 diabetes mellitus. Am. J. Physiol.-Ren. Physiol. 2015, 308, F77-F83. [CrossRef] [PubMed]

104. Chino, Y.; Samukawa, Y.; Sakai, S.; Nakai, Y.; Yamaguchi, J.; Nakanishi, T.; Tamai, I. SGLT2 inhibitor lowers serum uric acid through alteration of uric acid transport activity in renal tubule by increased glycosuria. Biopharm. Drug Dispos. 2014, 35, 391-404. [CrossRef] [PubMed]

105. Derosa, G.; Maffioli, P.; Sahebkar, A. Plasma uric acid concentrations are reduced by fenofibrate: A systematic review and meta-analysis of randomized placebo-controlled trials. Pharm. Res. 2015, 102, 63-70. [CrossRef]

106. Hamada, T.; Ichida, K.; Hosoyamada, M.; Mizuta, E.; Yanagihara, K.; Sonoyama, K.; Sugihara, S.; Igawa, O.; Hosoya, T.; Ohtahara, A.; et al. Uricosuric action of losartan via the inhibition of urate transporter 1 (URAT 1) in hypertensive patients. Am. J. Hypertens. 2008, 21, 1157-1162. [CrossRef]

107. Burnier, M.; Roch-Ramel, F.; Brunner, H.R. Renal effects of angiotensin II receptor blockade in normotensive subjects. Kidney Int. 1996, 49, 1787-1790. [CrossRef]

108. Waldman, B.; Ansquer, J.C.; Sullivan, D.R.; Jenkins, A.J.; McGill, N.; Buizen, L.; Davis, T.M.E.; Best, J.D.; Li, L.; Feher, M.D.; et al. Effect of fenofibrate on uric acid and gout in type 2 diabetes: A post-hoc analysis of the randomised, controlled FIELD study. Lancet Diabetes Endocrinol. 2018, 6, 310-318. [CrossRef]

109. Torralba, K.D.; De Jesus, E.; Rachabattula, S. The interplay between diet, urate transporters and the risk for gout and hyperuricemia: Current and future directions. Int. J. Rheum. Dis. 2012, 15, 499-506. [CrossRef]

110. Juraschek, S.P.; Miller, E.R., III; Gelber, A.C. Effect of oral vitamin C supplementation on serum uric acid: A meta-analysis of randomized controlled trials. Arthritis Care Res. 2011, 63, 1295-1306. [CrossRef]

111. Li, L.; Zhang, Y.; Zeng, C. Update on the epidemiology, genetics, and therapeutic options of hyperuricemia. Am. J. Transl. Res. 2020, 12, 3167-3181. [PubMed]

112. Su, X.; Xu, B.; Yan, B.; Qiao, X.; Wang, L. Effects of uric acid-lowering therapy in patients with chronic kidney disease: A meta-analysis. PLoS ONE 2017, 12, e0187550. [CrossRef] [PubMed] 
113. Vedder, D.; Walrabenstein, W.; Heslinga, M.; de Vries, R.; Nurmohamed, M.; van Schaardenburg, D.; Gerritsen, M. Dietary Interventions for Gout and Effect on Cardiovascular Risk Factors: A Systematic Review. Nutrients 2019, 11, 2955. [CrossRef] [PubMed]

114. Yang, X.; Yuan, Y.; Zhan, C.G.; Liao, F. Uricases as therapeutic agents to treat refractory gout: Current states and future directions. Drug Dev. Res. 2012, 73, 66-72. [CrossRef] [PubMed]

115. Pui, C.H. Urate oxidase in the prophylaxis or treatment of hyperuricemia: The United States experience. In Seminars in Arthritis and Rheumatism; W.B. Saunders: Philadelphia, PA, USA, 2001; Volume 38, pp. 13-21.

116. Sundy, J.S.; Baraf, H.S.; Yood, R.A.; Edwards, N.L.; Gutierrez-Urena, S.R.; Treadwell, E.L.; Vázquez-Mellado, J.; White, W.B.; Lipsky, P.E.; Horowitz, Z.; et al. Efficacy and tolerability of pegloticase for the treatment of chronic gout in patients refractory to conventional treatment: Two randomized controlled trials. JAMA 2011, 306, 711-720.

117. Baraf, H.S.; Becker, M.A.; Gutierrez-Urena, S.R.; Treadwell, E.L.; Vazquez-Mellado, J.; Rehrig, C.D.; Ottery, F.D.; Sundy, J.S.; Yood, R.A. Tophus burden reduction with pegloticase: Results from phase 3 randomized trials and open-label extension in patients with chronic gout refractory to conventional therapy. Arthritis Res. 2013, 15, R137. [CrossRef]

118. Lipsky, P.E.; Calabrese, L.H.; Kavanaugh, A.; Sundy, J.S.; Wright, D.; Wolfson, M.; Becker, M.A. Pegloticase immunogenicity: The relationship between efficacy and antibody development in patients treated for refractory chronic gout. Arthritis Res. 2014, 16, R60. [CrossRef]

119. Jansen, T.L.; Perez-Ruiz, F.; Tausche, A.K.; Richette, P. International position paper on the appropriate use of uricosurics with the introduction of lesinurad. Clin. Rheumatol. 2018, 37, 3159-3165. [CrossRef]

120. Scheepers, L.E.J.M.; van Onna, M.; Stehouwer, C.D.A.; Singh, J.A.; Arts, I.C.W.; Boonen, A. Medication adherence among patients with gout: A systematic review and meta-analysis. In Seminars in Arthritis and Rheumatism; W.B. Saunders: Philadelphia, PA, USA, 2018; Volume 47, pp. 689-702.

121. Zhao, Y.; Xu, L.; Tian, D.; Xia, P.; Zheng, H.; Wang, L.; Chen, L. Effects of sodium-glucose co-transporter 2 (SGLT2) inhibitors on serum uric acid level: A meta-analysis of randomized controlled trials. Diabetes Obes. Metab. 2018, 20, 458-462. [CrossRef]

122. Juraschek, S.P.; Appel, L.J.; Miller, E.R., III. Metoprolol Increases Uric Acid and Risk of Gout in African Americans with Chronic Kidney Disease Attributed to Hypertension. Am. J. Hypertens. 2017, 30, 871-875. [CrossRef]

123. Musini, V.M.; Nazer, M.; Bassett, K.; Wright, J.M. Blood pressure-lowering efficacy of monotherapy with thiazide diuretics for primary hypertension. Cochrane Database Syst. Rev. 2014, 5. [CrossRef] [PubMed]

124. Strilchuk, L.; Fogacci, F.; Cicero, A.F. Safety and tolerability of available urate-lowering drugs: A critical review. Expert Opin. Drug Saf. 2019, 18, 261-271. [CrossRef] [PubMed]

125. Xu, C. To switch or not switch febuxostat: Comment on the article by FitzGerald et al. Arthritis Rheumatol. 2020. [CrossRef] [PubMed] 